\title{
Bioprocessing Philosophies of Wheat Grain for Ruminants: A Postmodern Analysis
}

\section{Akbar Nikkhah*}

Chief Highly Distinguished Professor, Department of Animal Sciences, University of Zanjan, Iran

This editorial seeks to address the working bioprocessing philosophies of Wheat Grain (WG) for high-producing ruminants. Historically, WG has usually been considered as a highly fermentable starch and protein source that, if mismanaged in feeding, may most likely cause disturbances in rumen microbial metabolism and lead to subacute and acute forms of rumen acidosis $[1,2]$. Such a traditional threat has rather kept specialists and farmers from approaching WG for practical and efficient use in high-producing dairy ruminant diets. As a result, to date limited data exits on detailed mechanistic effects of differently dry and wet bioprocessed WG for ruminants of varying physiological states [3].

Wheat grain has several major varieties and cultivars most of which are considered highly degradable in rumen. However, few specific types have lower starch and protein fermentation rate due to their unique physiochemical structure of protein matrices surrounding starch granules, thereby reducing microbial exposure in the rumen $[4,5]$. Except for such slowly fermentable WG varieties, the practical philosophy in bioprocessing of WG is to synchronize heat and moisture treatment of wheat kernels to increase starch-protein, starch-fat, and protein-fat bounds to make WG kernels more gradually available and degradable to avoid organic acids accumulation in the rumen that would exacerbate the catastrophic consequences of subacute rumen acidosis on ruminant health and productivity [6]. For particular instance, steam-rolling or more extensively steam-flaking can help to develop the above intermolecular bounds in managing valoatile fatty acids, ammonia, and endotoxins release in the rumen. Recent discoveries and emphases clearly suggest that steam-flaking and to a lower extent steam-rolling help in effective controlling of barley grain rumen degradation rate.

Noteworthy, WG is on average even more degradable than barley grain. Thus, WG is expected to respond more significantly to steamrolling, when compared to barley grain. Steam-rolling requires shorter and unpressured steam-heat treatment of grains before passing through rollers [7]. As a result, steam-rolled grains are less extensively bioprocessed both physically and chemically, and thus, are less flat and denser than steam-flaked grains. It is expected that steam-flaking would be more suitable than steam-rolling for barley grain in reducing rumen degradation rates of starch and proteins, whereas steam-rolling may suffice accomplishing the goal for WG. Since steam-flaking demands more energy and time, it is more expensive and less economical than steam-rolling [8]. As such, making the right bioprocessing choice for WG (i.e., steam-rolling rather than steam-flaking) could significantly decrease costs and improve ruminant enterprise economics.

In a nutshell, effective communication among agriculturists, animal scientists, ruminant farmers, and veterinarian will increase awareness on the practicality of feeding WG to high-producing dairy and beef cattle when available most [9]. This must be followed by adopting optimal bioprocessing techniques that would produce coarse particles while effectively reducing starch and protein fermentation rates in the complex rumen environment. It is only through such delicate artistic management strategies that WG will offer an-farm treasure towards meeting energy and amino acid requirements of postmodern ruminants [10].

Future studies on differently steam-processed WG of differing endosperm nature for dairy and beef ruminants in varying production levels and physiological states are required to generate global guidelines for on-farm use [11]. Securing such information is a must to help minimize risks from metabolic disorders related to WG feeding mismanagement in high-yielding profitable ruminants.

\section{Acknowledgment}

The Ministry of Science Research and Technology and University of Zanjan gratefully thanked for supporting the author's global programs of optimizing the new millennium SciTech edification.

\section{References}

1. Doepel L, Cox A, Hayirli A (2009) Effects of increasing amounts of dietary wheat on performance and ruminal fermentation of Holstein cows. J Dairy Sci 92 3825-3832.

2. Faldet MA, Nalsen T, Bush LJ, Adams GD (1989) Utilization of wheat in complete rations for lactating cows. J Dairy Sci 72: 1243-1251.

3. Falkerson WJ, Michell PJ (1985) Production response to feeding wheat grain to milking cows. Australian Journal of Experimental Agriculture 25: 253-256.

4. Huntington GB (1997) Starch utilization by ruminants: from basics to the bunk J Anim Sci 75: 852-867.

5. Nikkhah A (2014) Wheat Grain for Transition Dairy Cows: A Multifaceted Abet or an Intriguing Risk? Advances in Dairy Research. In Press.

6. Nikkhah A (2011) Optimizing barley grain use by dairy cows: a betterment of current perceptions. Progress in Food Science and Technology 1: 165-178.

7. Nikkhah A (2012) Barley grain for ruminants: A global treasure or tragedy. J Anim Sci Biotechnol 3: 22.

8. Nikkhah A, Amiri F, Amanloo H (2012) Ground wheat grain for midlactation cows: challenging a common wisdom. ScientificWorldJournal 2012: 247941.

9. Nikkhah A, Ehsanbakhsh F, Zahmatkesh D, Amanlou H (2011) Prepartal whea grain feeding improves energy and calcium status of periparturient Holstein heifers. Animal 5: 522-527.

10. Amanlou H, Zahmatkesh D, Nikkhah A (2008) Wheat grain as a prepartal cerea choice to ease metabolic transition from gestation into lactation in Holstein cows. J Anim Physiol Anim Nutr (Berl) 92: 605-613.

11. Nikkhah A, Ghorbani GR (2003) Effects of dry and steam processing on in situ ruminal digestion kinetics of barley grain. Journal of Animal Science 81: 338

*Corresponding author: Akbar Nikkhah, Chief Highly Distinguished Professor Department of Animal Sciences, Faculty of Agricultural Sciences, University of Zanjan, Zanjan, Iran, National Elite Foundation, Tehran, Iran, Tel: +98-24-350-328 01; Fax: +98-24-350-332-02; E-mail: nikkhah@znu.ac.ir

Received October 30, 2014; Accepted October 30, 2014; Published November 03, 2014

Citation: Nikkhah A (2014) Bioprocessing Philosophies of Wheat Grain for Ruminants: A Postmodern Analysis. J Bioprocess Biotech 4:e115 doi: 10.4172/2155-9821.1000e115

Copyright: (c) 2014 Nikkhah A. This is an open-access article distributed unde the terms of the Creative Commons Attribution License, which permits unrestricted use, distribution, and reproduction in any medium, provided the original author and source are credited. 